\title{
Research on the Mode of Cultivating Business Applied Talents in Business English Teaching in Harbin University of Commerce
}

\author{
Lu Sun ${ }^{1, a^{*}}$ \\ ${ }^{1}$ Harbin University of Commerce, Harbin, China, 150028 \\ aSUN_LU1980@163.com
}

Keywords: Harbin University of Commerce; model research; business English

\begin{abstract}
This paper puts forward how to further deepen the reform of the business English teaching mode, improve the quality of business English teaching, establish a more perfect curriculum construction system and the concrete course of the study of the business situation, curriculum and teacher situation of business English in Harbin Commercial University. Measures to cultivate a new type of senior business talent to meet the challenges of the new century.
\end{abstract}

\section{Introduction}

With the acceleration of the global economic integration process and the deepening of China's economic reform and opening up, especially since the accession to the WTO, China's economic cooperation with the rest of the world is increasing. China's enterprises are toward the group, international development, foreign companies, joint ventures in China is also sudden emergence. The demand for foreign language talents has been diversified, "the traditional single foreign language professional knowledge and basic skills talents" has been far from meeting the needs of the market, the social needs of the "English language + professional knowledge" of the compound foreign language talent The In view of this, it is of great significance to explore how to set up the business English specialty of our school so that our business English teaching can meet the social and economic needs of rapid development and cultivate the talents of business application in the 21 st century.

\section{The Current Situation and Existing Problems of Business English Teaching in Our University}

Business English teaching is not a simple general English language teaching, its purpose is to cultivate students in the international business business ability and adaptability. It is more professional than the general English majors. It requires students not only to have the basic knowledge of English language, but also to be familiar with business knowledge and to be proficient in business English with professional terminology. Our business English majors are new in 2010. Recruit the size of the students, from the beginning of the two classes to three classes. The whole business English teaching is based on the curriculum of business English in the 1990s, that is, on the basis of traditional language knowledge and business courses, the addition of English professional knowledge courses and English background courses, and to develop a set of teaching Plan, in the teaching made some progress. But in the curriculum, teacher building, teaching mode, there are still some problems and shortcomings, to be further improved and improved.

\section{Suggestions and Measures for Reforming Business English Teaching in Our University}

Our business English major is four years of specialist teaching. In the teaching process, how to arrange the course reasonably, how to allocate the teaching time and practice time reasonably, how to reasonably grasp the proportion of theoretical teaching and practice teaching total is the urgent problem that we need to study and discuss urgently. In the English professional curriculum, we should first consider the level of students, teaching should highlight the practical and technical training model. The specifications of foreign language talents in the 21 st century are "language base + professional knowledge + application ability type". Business English teaching must be English as 
a means of access to professional knowledge and tools, and other professional such as foreign trade, finance, economic management and other areas linked to, and not just to learn the language and teaching language. Therefore, in the basic course of language teaching should focus on training and training of English language listening, speaking, reading, writing, translation and other basic skills, the curriculum can include comprehensive English, listening, speaking, reading, writing, translation (including Interpreting and translating).

To cultivate a professional knowledge of high-quality business English talents, must have a high-quality high-quality professional teachers. But at present, the teachers of business English teaching in our university are mostly rotated by TEFL. Teachers have the ability and experience of ordinary English, but they do not have the formal system of business English and business expertise. Teachers' business English knowledge and expertise are in urgent need of comprehensive, systematic professional training. Therefore, to strengthen the construction of teachers, is the urgent need to solve the problem. I believe that in addition to teachers to strengthen their own professional knowledge to learn and improve their professional knowledge and business level, the school should also actively encourage teachers to adapt to their own way.

The collaborative teaching model mainly emphasizes that the teaching activities should be centered on the students, and the teaching should be conducted in a combination of teacher teaching, teacher-student discussion and teacher-led group discussion. The use of collaborative teaching method, we must first deal with the role of teachers and students in teaching. Teachers are no longer the protagonist, but the classroom teaching activities of the designers, participants and guides, the protagonist is played by the students. Second, teachers should focus on the content of the teaching of the scouring of knowledge in the best way to students, so that they can in the shortest possible time to take the most valuable and most effective knowledge of the information; teachers should use the effective classroom teaching language, Teaching content throughout the classroom activities, to set up teaching activities, to stimulate students in the teaching activities of their own language skills and language strategies used to actively think, participate in teaching activities, to cultivate students' creativity.

In order to enable students to combine professional knowledge and English knowledge, they can express professional terms and professional content in skilled English. The author recommends that the courses on business English, such as international trade practice, marketing and international settlement, Bilingual "teaching model. "Bilingual" teaching can break the traditional single mother tongue teaching method, so that the integration of Chinese and English language, to achieve the transfer of Chinese and English language information, so that students can use more smooth English to participate in some business negotiations, read some professional English Newspapers, can accurately capture the international business information, can use the tool book translation professional articles, can write English business letters in general, so as to lay the foundation for the employment after graduation. Of course, this teaching model requires teachers and students should have a certain level of English. Taking into account the actual level of English students in our school, at the beginning of the implementation of "bilingual" teaching, the first Chinese-based, English as a supplement, and then gradually expand the teaching in English to teach the proportion of students to improve the level of business English proficiency.

The rapid development of modern science and technology, for business English teaching provides a broad space, the use of multimedia network technology can receive a multiplier effect. Our teaching experience has the following two experiences. First, make full use of multimedia network technology, will view, listen, say, translation and other teaching content into one through the computer multimedia to provide a variety of media tools, made easy to understand, set sound, figure, text, animation as one Lively teaching software. In the software production, pay attention to the composition of the color, prompt feedback language, sound picture, interactive questions, self-test practice and so on, for students to create a fascinating classroom atmosphere, so that students in an environment of interest to learn, so that the computer not only become a student Of the teachers, but also become their learning friends. Second, the use of computer multimedia to provide online functions to carry out business English simulation teaching model in order to enable 
students to learn the books quickly applied to the practice of knowledge, so that the real use of teaching, teaching can use computer multimedia to carry out online business simulation negotiations Of teaching.

\section{To Establish a Business English Professional Training Base}

Strengthen the practice of teaching, training students the ability to use language, in practice to impart knowledge to students, but also a very important part of business English teaching. Now, many vocational colleges in China have increased the implementation of the "school-enterprise integration" efforts, I believe that our school business English professional to do the characteristics of our school students in the community more competitive, Improve the visibility of our school, it should be as soon as possible with Guilin or Guangxi District and even some of the country's strong enterprises, foreign trade companies, hotels, hotels, communications and other industries to establish a partnership so that they can become our school students training base, So that students learn the theoretical knowledge can be applied to practice in time for them later on the job, direct service to the community, simplify the employment links, lay a good foundation.

\section{To Increase the Intensity of Educational Technology Training, Optimization of Foreign Language Teaching Information Team}

Increase the training of foreign language teachers. Improving the overall quality of foreign language teachers is the most important issue to realize the teaching informatization. Foreign language teachers' education modernization skills are lagging behind, which has become a bottleneck restricting the information of foreign language teaching and learning. The school should be based on modern educational technology theory, from synchronous and asynchronous, remote and face-to-face advantages, by learning, lectures, seminars, online remote consultation and other training mode of informatization training of foreign language teachers, improve the teachers' teaching foreign language information theoretical level and technical ability.

Increase the intensity of the training of students. The cultivation of students' information skills and information literacy is not only the basis of promoting the information of foreign language teaching, but also one of the objectives of the implementation of information technology in foreign language teaching. Schools should pay more attention to the training of basic skills of students, the organization of educational technology experts to carry out special training on educational skills of students, including the basic knowledge of computer network applications, the use of network teaching platform, etc.. Through training, improve the students' computer network skills, strengthen students' knowledge of foreign language teaching information, and guide students to learn from the Internet to learn to change.

\section{Conclusions}

As China's economy and the world's economic cooperation and two-way investment in the growing business English will be more endless opportunities for development and potential, it will be in the international economic and trade exchanges will play a more active role. However, with the opportunity at the same time, also has a greater challenge. Therefore, the business English teaching must be based on the ability of communication as the main line, the main line of language practice, and comprehensively improve the quality of students' comprehensive professional English, so as to more effectively adapt to social and economic needs of business English compound talents.

\section{Acknowledgements}

This paper is supported by Philosophy and Social Scientific Research Project Foundation of Heilongjiang Province (No.14C009). 


\section{References}

[1] Wei Chuanli, Practice and theoretical basis of public management research in China, China Electronic Commerce .2012. (10)

[2] Wei Chuanli, On the Problems in the Study of Public Administration in China, China's Foreign Trade .2012 (8)

[3]Sun Lu, Study on Self-learning of Business English Students by Network, MEICI2015, 2015.10

[4]Sun Lu, The Practice of Business English Cooperative Learning in the Network Environment, ICEMC2016,2016.05

[5] Sun Lu, raining of Foreign Trade-Oriented Business English Major, ICEMC2016,2016.05

[6]Sun Lu, On Using Podcasting to Teach in Mobile Foreign Language Learning, EMCM2016,2016.12

[7]Sun Lu, Discussion on the Reform of Foreign Language Teaching in College, EMCM2016, 2016.12

[8] Sun Lu, Discussion on the Training Mode of Business English Major, EMCS2017.05

[9] Sun Lu, Study on Business English Teaching, EMCS2017.05

[10] Wei Chuanli, SME technical efficiency and scale revenue calculation methods and selection of indicators, Computer modeling and new technologies,2014.12 